\title{
Debates on Social Exclusion and \\ Inclusion in Nepal
}

$\sim$ Dipesh Ghimire $^{1}$

\begin{abstract}
The term "Social Exclusion" is used to describe a wide range of phenomena and processes related not only to poverty and deprivation, but also to social, cultural and political disadvantages, and in relation to a wide range of categories of excluded people. However, there is no single way of understanding the concepts of social exclusion and inclusion. In the context of Nepal, power was consolidated by interlinking it with the Hindu caste system. The social order was exclusionary because it classified all groups as distinct castes within the broad framework of the Hindu system of the four varnas based on concepts of ritual purity and pollution. This paper has attempted to present a quick and preliminary discussion on theoretical perspectives on social exclusion and inclusion. The paper has also emphasized on the major debates on social exclusion and inclusion in Nepal and thematic aspects of social exclusion and inclusion.
\end{abstract}

Keywords: Social Exclusion, Social Inclusion, Madhesi Community

\section{Introduction}

The terms "social exclusion" is relatively of recent origin. Rene Lenoir, writing in 1970s is given credit of authorship of the expression. The notion has, however, already made substantial inroads into the discussions and writings on poverty and deprivation. There is a large and rapidly growing literature on the subject (Sen, 2000, De Haan 1997, Silver 1995, Saith, 2001). Similarly, the terms social exclusion and inclusion originated from Europe in response to the fear of social disintegration and crises of the welfare state caused by social and economic crises, but have now become worldwide, including Nepal. Many authors (silver 1994, de Haan 1999, Sen 2000) have noted that the term 'social exclusion' is polysemic in that it has many meanings. The term is used to describe a wide range of phenomena and processes related especially to poverty and deprivation, but also to social, cultural and political disadvantages, and in relation to a wide range of categories of excluded people. Social exclusion and inclusion are 'contested concept', defined from the perspective or framework of different social 1 Ghimire is an Assistant Professor at the Central Department of Sociology, Tribhuvan University 
science paradigms and disciplinary and theoretical perspectives, political ideologies and even national discourses (Silver 1996, de Haan 1998).

It is not surprising then that questions have been raised as to whether these terms especially social exclusion, add value, as the economists would say, to the concepts of poverty, relative deprivation and disadvantage (Sen 2000, de Haan 1998, Saith 2001); about the scope or range of social phenomena that these concepts cover; whether the concepts are applicable to the so-called southern countries (de Haan 1998, Sen 2000) and about the relations between social exclusion and social inclusion (Sen 2000). Moreover, invoking these terms has moral and political implications, exclusion is 'bad', inclusion is 'desirable' and we need to find ways to include the excluded. Given these and other questions, it is perhaps not without cause that some critics that researchers "pick up the concept and are now running all over the place arranging seminars and conferences to find a researchable content in an umbrella concept for which there is limited theoretical underpinning" (Sen 2000, de Haan 1998). However, there is no single way of understanding the concepts of social exclusion and inclusion. Many authors raise the issue of the value added by the concept of social exclusion and whether the concepts are relevant for the so-called developing countries, the summarize that social exclusion is an improvement over the older and related concept of poverty, relative deprivation, capabilities, etc, and that could be used for the South.

In this paper, I shall attempt a quick and preliminary discussion of the approaches or theoretical perspectives on social exclusion and inclusion. I shall also emphasize the major debates on social exclusion and inclusion in Nepal. In this paper I have discussed the thematic aspects of social exclusion and inclusion. I have divided this paper into four sections, first introduction, and second understanding of the social exclusion and inclusion, third, the major debates on social exclusion and inclusion in Nepal, and finally conclusion.

\section{The Concepts of Social Exclusion and Inclusion}

There are many definitions of the concepts of social exclusion and inclusion. The definitions have changed over time and differ according to the theoretical perspective or paradigms used. Social exclusion is usually defined as a dynamic process of progressive multidimensional rupturing of the 'social bond' at the individual and collective levels. Social bond means the social relations, institutions, and imagined identities of belonging, constituting social cohesion, integration or solidarity. Silver (2007) stated that the rupture of the social bond can take many forms: abandonment, segregation, assistance, marginalization, and discrimination. Social exclusion precludes 
full participation in the normatively prescribed activities of a given society and denies access to information, resources, sociability, recognition, and identity, eroding selfrespect and reducing capabilities to achieve personal goals (Silver 2007).

DFID (2009) has defined social inclusion as if any community experiences being deprived of participation and profit gaining on the basis of caste, gender, ethnicity, genetics, religion, age, different kinds of abilities, HIV status, residents or migration status. It is generally accepted that the term social exclusion originated from Europe, especially in France in the early 1970s first to describe various categories of people like mentally and physically disabled, the aged, abused children, single parents, who were excluded from the employment based on social security system. The term was continually redefined to encompass new problems and social groups. It was used in the 1980 s to refer to various types of social disadvantage related to social problems arising from economic crises and crises of the welfare state-long term unemployment, growing instability of social bonds including among family members, in neighborhoods, trade unions, etc, but also of the lack of integration of immigrants, especially Muslims (Silver 1994). Exclusion was seen as the result of the rupture of social and symbolic bonds between individuals and society and the failure of the state, reflecting the French emphasis on the organic and solidarity of society. Social policy was directed towards 'insertion' or integration of the excluded to ensure social cohesion or social solidarity (Silver 1995, de Haan 1999).

The term gradually spread over Europe and in 1989 the European Commission (EU) passed a resolution to fight 'social exclusion' and foster 'integration'. In a short time this term replaced, or at least threatened to displace as the dominant concept, poverty in development and social policy discourse in Europe (Silver 1995). The term then, fostered no doubt by international agencies spread to Asia, Latin America and Africa, with very different social, economic and political conditions, where it competes for discursive dominance, with the more established terms such as poverty, relative deprivation, social disadvantage and the like. While some authors (Sen 2000, de Haan 1999) raise the issue of the relation between these two concepts, the one originating in Europe and the other applied to developing countries, they conclude that social exclusion is an improvement over the older and related concept of poverty, relative deprivation, capabilities etc. However Saith (2001) disagrees, he argues that: "Since it is difficult to apply the 'social exclusion' concept to developing countries, in the context of the welfare state and formal employment, attempts to modify and apply it have largely resulted in a repetition and relabeling of poverty studies that have already been carried out in developing countries." 
Some definitions emphasize exclusion from full participation in community or society as an essential element of social exclusion, while others emphasize other elements such as citizenship and social rights. A social exclusion concept can provide context-specific frameworks for the analysis and policy, which may also provide a link to debates about participation. It starts from a general idea of the importance of integration in society, but the way this is operationalized can and should be dependent on local circumstances (de Haan, 1999).

Similarly, social inclusion is a distinct project with its own logic. Jackson (1999) argues that there can be simultaneous exclusion and inclusion, that is individuals and groups can be excluded in one domain and included in another.

Young (2000) points out that there may be grounds for the critics of political inclusion to argue that inclusion may presuppose "an already given set of procedures, institutions and the terms of the public discourse in to which those excluded or marginalized are incorporated without change."

While reviewing these literatures social exclusion is the exclusion from social economic and political process. It is a dialectical process and relationships that stop individuals and particular groups from the accessing and controlling different resources, participating and engaging in the public spheres of the society and claim their rights and not able to proper deliver their responsibility towards society.

\section{Major Debates on Social Exclusion and Inclusion in Nepal}

Nepal is a Hindu-dominated society. It has excluded four groups of people from the contemporary development processes. Some are facing the political exclusion others economic exclusion and some have been facing the socio- cultural exclusion in Nepal. These four groups are first, Dalits, second Madheshi or Terai people, third one is Ethnic/ Indigenous people and finally Women.

In the context of Nepal, power was consolidated by interlinking it with the Hindu caste system. The social order was exclusionary because it classified all groups as distinct castes within the broad framework of the Hindu system of the four varnas based on concepts of ritual purity and pollution. The Hindu caste system traditionally categorized people into four groups Brahmin (scholars and priests) at the top, Chhetri (warriors) just below, then the Vaishya (merchants and traders), and lastly, Sudra (peasants/ laborers) (Dumont, 1998). The Muluki Ain (Civil Code) of 1854 legally formalized the highly rigid and hierarchical caste system and brought the Adivasi Janajatis (nonHindu indigenous nationalities) into the system with middle-rank status (Hofer, 2004). This caste-based discrimination was abolished legally in 1963. 


\section{Dalit Community and Issue of Social Exclusion and Inclusion}

The Dalit community in Nepal is not only discriminated to use and have access to public utilities and places but also excluded from the legal system and public policies. Through laws and plans the government has been intervening in increasing the participation of Dalits in local and central governance mechanism. Yet, the results of such nominal policies have been proved as tokens and can be labelled as formal inclusive only. Often Dalit activists and people/institutions working for Dalits raise their voices on pertinent issues like untouchability, discrimination, poverty, social prejudice and cultural barriers, inaccessibility in resources, and lack of representation in governance and political system.

The development and nation building process are very exclusionary. Dalits among others are being excluded from this process. Many development practices make it possible for the local elites to capture the benefits of the development project and programs at the cost of the really disadvantaged. If we look at everyday life of the Dalit people, there are different forms of exclusion in the community level. However the processes, mechanisms and institutions of exclusions may different according to time and space.

\section{Regional Exclusion and Madhesi community}

Madhesi community have a long history of origin and habitat in the Madhes region of Nepal. However they are facing the blame of "outsiders". This community is continuing to be marginalised and have faced exclusion in political, administrative, governance mechanism, policy formulation process and decision making spheres. Still they have been facing the different problems e.g. citizenship, identity, language and their own native land. The Madhesi people feel highly discriminated against and has almost lost 'the sense of belongingness to this nation' the exclusion of the Madhesi community from the national mainstream has been a negative factor for the sound economic development in the country. Gaige (1976) argues in his popular book "Regionalism and National Unity in Nepal," Terai is the main economic hub of Nepal. However it is excluded from mainstream socio-economic, political, cultural and administrative debates of Nepal. They are facing many problems due to the politics of language, education, communication, citizenship and participation in the decision making process not only in central level but also in local. While making plan and policies by government in national programme, Pahadis were included but high population of Madhes were excluded (Ghimire, 2013).

Madhesi people are treated as 'less Nepali' or 'non-Nepali' by Pahadi people. Madheshi people and community have not been fully integrated in the national political, socioeconomic and cultural part and agenda of the nation. They have been excluded from 
the national mainstream. There is widespread feeling among the Madheshi community that they have been strongly discriminated and are not given proper opportunity in the country. Many of the modern day basic facilities have not yet reached Madhesi people. There has been little effort to prevent social, economic and political exclusion and to reintegrate those who have become excluded through unemployment, landlessness and homelessness.

\section{Social Exclusion and Indigenous Nationalities}

Nepal always remained a multi-ethnic and diverse country without having any core ethno-federal region. There has been rise on ethnic awareness after the establishment of democratic system in Nepal, yet the political mobilization of ethnicity by elites would not have been possible without the political incentives to mobilize it.

After the re-establishment of democracy in 1990, grievances of disadvantaged and marginalized groups started to raise their voice. During the multi-party democratic period no party has completed even single full term of its tenure in the government. The government has not given an importance to incorporate the ethnic and indigenous nationalities in the mainstream of the nation. Due to the power struggle between the national political parties, ethnic groups had been oppressed by the center.

Susan Hangen (2011) convincingly articulates her research on the rising influence ethnic groups and peripheral areas have had on Nepal's democratization since the adoption of a multi-party democratic system in 1990. Hangen makes compelling efforts to illustrate how the margins - understood as 'political peripheries of the state' dwelt by 'marginal populations' developing 'non-hegemonic discourses' such as ethnic inequality have construed, experienced and participated in democratic politics and democratization processes in contemporary Nepal. Hagen argues that ethnic inequality has a long history in Nepal and is deeply rooted.

\section{Social Exclusion and Women}

Women are also socially marginalized and excluded groups in Nepal. The exclusion has been seen by connecting with discrimination, dissimilarities and violence. This is incomplete and inappropriate in itself in this sense that the women exclusion is not only limited to hierarchical structure and dissimilarities but this should be seen as the result of rejection and isolation of presence of women on socio-economic, political and various other sectors (Tuladhar, 2069 B.S.).

The basis of Nepalese women movement has been seen as individual initiatives. Similarly, the commencement of women social awareness and whole nation's political 
movement has been made by connecting with individual initiatives. As an example, the demand of Chandrakanta Malla in 1993 B.S. for daughters to go to school has been first demand till date. Similarly, the participation of Rewantdevi Acharya and Kamakshyadevi in Nepal Prajaparishad which was established in the year 1997 B.S., are the major ones (Panta, 2051 B.S.).

After the political change in the year 2007 B.S., the women inclusion went on increasing. Though there was no much work in the women inclusion during the Panchayat regime, the women inclusion in politics was increased noticeably. The contemporary undergrounded parties had given special attention on women inclusion. The sixth amendment on legal code in 2033 B.S. gave some rights to women. By restricting child marriage and polygamy, the amendment on legal provisions like women property, Anshabanda (sharing of property between/among legally entitled individuals), women trafficking and prostitution and rape etc was made (Panta, 2051 B.S.).

For the first time in the constitutional history of Nepal, the people's movement 1990 made provision of 5 percent women candidate for parliamentary was compulsory for the participation of women in political mechanism. Similarly, the provision of 20 percent women representative from each ward level was made compulsory in 2054 B.S. local election. The Constitution of Nepal 2072 B.S. made provision for women participation in legislative parliament to be at least 33 percent.

Despite this positive indicator, lack of specific law to address the violence against women and domestic violence, apathy of government towards the victims, hypocrisy of the Nepali society and transitional situation of the nations are the hindrance to overcome to reach the destination.

\section{Conclusion}

The notion about social exclusion varies from one to another society depending upon the changing context. Exclusion has been a cause and result of unequal development in Nepal. Development outcomes across all sectors show that gender, caste, ethnicity, regional identity, and economic status are strong determinants of access to services, resources, and political representation. The inclusion agenda is now firmly placed in the development discourse and several efforts have been initiated at the policy, legal, institutional, and programming levels. Policy and program approaches that can contribute to removing these barriers include attention to identifying the excluded, the causes of their exclusion, and appropriate context-specific responses. 


\section{References}

Acharya, Rameshwor. (1988), Nepalma Mahila Bikaska Prayas Tatha Kanuni Pravadhanharu. Kathmandu: Panchayat Darpan 11 (1): 61. (In Nepali).

Askonas, P. and Angus Stewart (2000) Social Inclusion: Possibilities and Tensions. New York: St. Martin's Press.

Beall, J. and L.H. Piron (2003) DFID Social Exclusion Review. London: LSE/ODI.

Constitution of Nepal (2072 B.S.) Kathmandu: Nepal Law Commission, Nepal available at http://www.lawcommission.gov.np/en/documents/2016/01/constitution-ofnepal-2.pdf Accessed on 30 July 2017.

de Haan, A. (1999) Social Exclusion: Towards an Holistic Understanding of deprivation, Social Development Department, Dissemination Note No.2, Department for International Development,

de Haan, A. (1999). Social exclusion: An alternative concept for the study of deprivation? IDS Bulletin 29 (1): 10-19.n.d. Social exclusion: Enriching the Understanding of Deprivation.

de Haan, A. and Simon Maxwell (eds.) (1998), Poverty and Social exclusion in North and South. IDS Bulletin 29 (1).

DFID (2009), Research Program Consortia, Guidance Note on Gender Mainstreaming and Social

DFID and World Bank. (2006). Unequal Citizen: Gender, Caste and Ethnic Exclusion in Nepal: A Summary Report. Kathmandu: The World Bank and the Department for International Development.

DFID/World Bank (2005) Summary Report. Citizens with(out) Rights: Nepal Gender and Social Exclusion Assessment. Kathmandu: DFID/World Bank.

Dumont L. (1998) Homo Hierarchicus: The Caste System and Its Implications. New Delhi: Oxford University Press.

Ghimire D. (2013). Madhesh Bidroha: Karan, Upalabdhi ra Chunauti. In Madhesh Adhya: 1: 33-57. (In Nepali).

Hangen, S (2011), The Rise of Ethnic Politics in Nepal: Democracy in the Margins. London: Routledge 
Hofer, A. (2004), The Caste Hierarchy and the State in Nepal: A Study of Muluki Air 1854. Himal Books: Lalitpur.

Jackson, C. (1999). Social exclusion and gender: Does one size fit all? The European Journal of Development Research, 11 (1): 125-146.

Kabeer, N. (n.d). Social exclusion, poverty, and discrimination: Towards an analytical framework. London, U.K.

Panta, S. (2051 B.S.). Nepali Nariharu Asmita ko Khojima. Ashmita, Year 7, Issue 25, Kathmandu: Asmita Mahila Prakashan Griha. (In Nepali).

Reimann, C. (2004), Gender in Problem-solving Workshops: A Wolf in Sheep's Clothing? Swiss Peace Working Paper, 3/2004, p.8, Switzerland: Swiss Peace Foundation.

Room, G.J. (1999) Social exclusion, solidarity and the challenge of globalization. International Journal of Social Welfare, 8: 166-174.

Saith, Ruhi (2001), 'Capabilities: the concept and its Operationalization', QEH Working paper, Oxford University.

Sen, A. (2000) Social exclusion: Concept, application, and scrutiny. Manila: Asian Development Bank. (Social Development Papers No. 1).

Silver, H. (1994) Social exclusion and social solidarity: Three paradigms. International Labour Review, 133: 531-578.

Silver, H. (1994), Social exclusion and social solidarity: Three paradigms. International Labour Review, 133:531-578.

Silver, Hillary (1995) 'Conceptualizing social disadvantage: three paradigms of exclusion, in Rodgers, G. et al. Social Exclusion: Rhetoric, Reality and Responses, Geneva: International Labor Organization.

Silver, Hillary (2007) the Process of Social Exclusion: the Dynamics of an Evolving Concept, Brown University.

Tamang, Sera (2000), Legalizing State Patriarchy in Nepal, in Studies in Nepali History and Society, Vol 5, No 1, pp. 127-156.

Thapa, Krishna (1985), Women and Social Change in Nepal (1951-1960). Kathmandu: Mrs. Ambika Thapa. 
Timilsina, Prakash.(2069 B.S.). Samabeshi chhaina Maobadi. Kathmandu, Nagarik Daily, Bhadra 9 p.3 (In Nepali).

Tuladhar Indu. (2069 B.S). Samabeshikaran ra Mahila Sarokar. Editor: Rajendra Maharjan: Kathmandu, Rupantran Samaj Adhyan, Puranka 8, 2069 Bhadra, CoCAP, Nepal. (In Nepali).

Tuladhar, Indu. (2064 B.S.). Mahila Dwara Parivashit Rajya Ko Punarsamrachana. Kathmandu: Center for women, Peace and Democracy. (In Nepali).

UNDP (2010). Samajik Samabeshikaran, Sambaidhanik Sawal haruma Jankarimulak Samagri. Kathmandu: SPCBN/UNDP. (In Nepali).

Young, I.M.(2000), Inclusion and Democracy. Oxford: Oxford University Press.

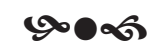

